\title{
長期呼吸補助用人工肺の開発 Development of an Oxygenator for Long term Lung Assist
}

\author{
片桐伸将(正会員), 舟久保昭夫(正会員)*, 福井康裕(正会員)* \\ Nobumasa Katagiri, Akio Funakubo*, Yasuhiro Fukui*
}

\begin{abstract}
This paper describes a membrane oxygenator for long term lung assist.

A Membrane Oxygenator has been used for extracorporeal circulation as ECMO. However, the major oxygenators which have microporous membrane cause plasma leakage that deteriorates the performances for long term circulation. The authors developed a fine silicone hollow fiber which is twice the mechanical strength, low diameter and thin wall thickness. The fine silicone hollow fiber has almost the same transfer performance as microporous hollow fiber when it used in extracapillary flow type. However, extracapillary flow type which causes partial and accumulate flow easily has possibility of causing thrumbus and reduction of gas transfer performance.

On the other hand, an intracapillary flow type oxygenator can make laminar flow in the hollow fibers. It is able to keep gas transfer performance stably for long term circulation without thrumbus. One of the disadvantages of intracapillary flow type is large pressure drop. Therefore, using softness of the silicone material, the authors designed and manufactured an oxygenator which has expanded inlet for decreasing pressure drop. This intracapillary oxygenator consists of 25000 silicone hollow fibers with a length of $8 \mathrm{~cm}$ inserted in the housing. The surface area of the membrane is $3.0 \mathrm{~m}^{2}$. The priming volume is $390 \mathrm{~mL}$. Gas transfer performance of the oxygenator was evaluated by in vitro experiments. Oxygen and carbon dioxide transfer rate were $52 \mathrm{~mL} / \mathrm{min}$ and $95 \mathrm{~mL} / \mathrm{min}$, and pressure drop was $30 \mathrm{mmHg}$ at a blood flow rate $1 \mathrm{~L} / \mathrm{min}$. The oxygenator developed in this study can be used for extended duration in such application as extracorporeal membrane oxygenator.
\end{abstract}

Key words

Extracorporeal circulation, Silicone hollow fiber, Intracapillary oxygenator, Expanded inlet, Pressure drop

\section{1. 緒言}

膜型人工肺はその性能向上に伴い，開心術のみならず，補 助循環あるいは $\mathrm{E} \mathrm{CMO}$ 等の数週間から数力月に渡る長期呼 吸補助に使用されるようになった。 しかし, 長期呼吸補助の 場合, 膜の耐久性の面で現在広く使用されている多孔質膜で は血漿漏出によるガス交換能の低下等問題がある はこのような問題の生じない耐久性に優れたシリコーン中空 系膜を従来の 2 倍に高強度化, 小口径化を図った新規シリコ 一ン中空糸膜を用いて, 外部灌流方式において多孔質膜に劣 らない高ガス交換能を得だの。この外部灌流方式では血流 が中空糸外側を流れ, 複雑な流れを呈するため, 血液側の境 膜抵抗が破壊されガス交換を促進している゙ カ8).しかし,

1997年 1 1月 27 日受付

1998年 7 月 3 日受理

職業能力開発大学校 福祉工学科

*東京電機大学 応用電子工学科

T229-11 神奈川県相模原市橋本台4-1-1

* $=350-03$ 埼玉県比企郡沜山町石坂

Dept. of Rehabilitation Engineering, The

Polytechnic University.

*Dept. of Applied Electronic Engineering, Tokyo

Denki University.

4-1-1 Hashimotodai, Sgamihara, Kanagawa 229-

11, Japan. 'Ishizaka, Hatoyama, Hiki, Saitama, Japan
この方式では血液が中空糸束間を自由に流れることができる ため, 血液の偏流や滞流が生じ易く, 長期使用においてはカj 又交換能の低下や血栓を招き問題となる。このため, 中空系 の配糸法や人工肺形状の改善が求められているい．一方内部 灌流方式であれば，血液が中空糸内側をほぼ一様に流れるた め, 血液の滞流も少なくでき, 安定したガス交換能を得るこ とが可能になるが，血液側圧力損失が大きくなる゙ため一部 長期呼吸補助を除いて使用されていない.

そこで柔軟性のあるシリコーン中空糸膜の特徵を利用して， 圧力損失を低減する為に, 中空糸流入部を流体力学的な損失 係数の低い形状にすることを試みた。そして圧力損失低減効 果を持つ内部灌流型人工肺を試作し, 压力損失, ガ不交換性 能の評価を行い，長期呼吸補助用人工肺としてその有用性が 示唆されたので報告を行う.

\section{2.方法}

\section{1流入部の作製}

まず中空糸流入部において血流が急に狭い中空糸内を流机 ることを強いられるために生じる圧力損失および円管状流路

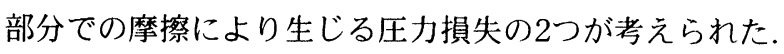

このため, まずシリコーン中空糸膜の柔軟な性質を利用し て, 円管状流路の流入部である中空糸断面を抎張し, 損失係 
数の低いラッパ状にすることで縮流を防ぎ圧力損失を低減で きると考えた.

ここで，一般的に中空糸膜型人工肺は，円筒状の容器（ハ ウジング）に外径数百 $\mu \mathrm{m}$ の空糸数千本の束を充填し，そ の円筒の両端に接着剤を遠心力を付加しながら流し込み（ポ ッティング)，加熱する. そして固着した後, ハウジング両 端に突出した接着片部分を切断することにより，製作される。 そこで，この手法を基本に，ポッティング作業を多段階に分 け，ポッティング部分を拡張することで，ラッパ状の中空糸 流入部の作製を試みた。

まず，拡張により中空糸断面の拡大化が可能であるかを試 験片を用いて確認することとした．第1段階では，内径300 $\mu \mathrm{m}$, 外径 $400 \mu \mathrm{m}$ のシリコーン中空糸膜をそれと同じ材質 の液状シリコーンゴム（RＴVゴム）を用いてポッティング を行い, 固着後このポッティング部分を厚さ $2 \sim 5 \mathrm{~mm}$ にカ ットし試験片を作製した.

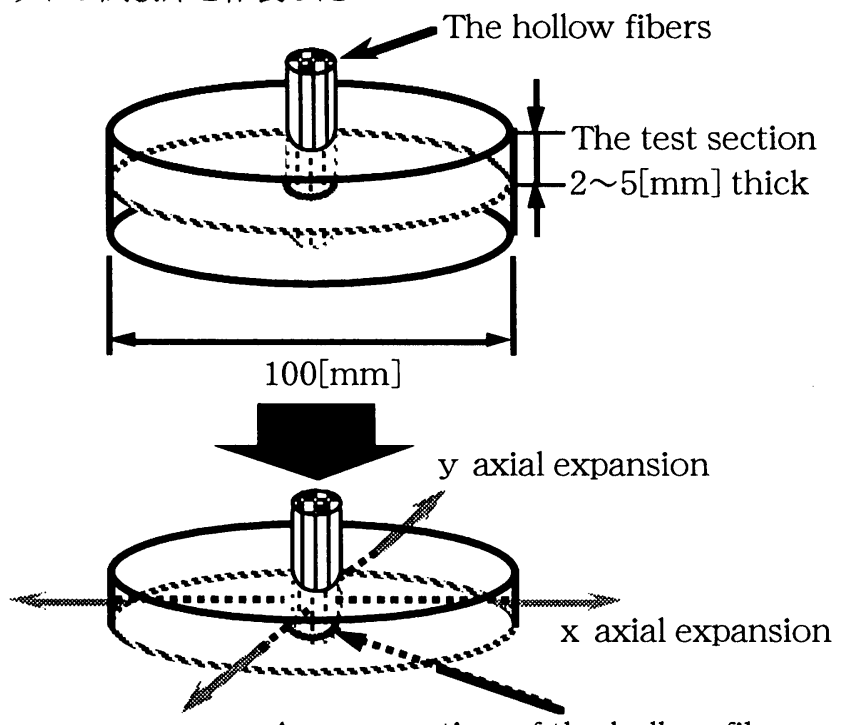

A cross section of the hollow fibers

Fig.1 A schematic diagram of the experiment of Expanding hollow fibers section

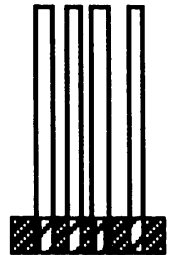

(a)

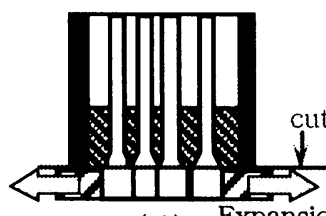

(d) Expansion

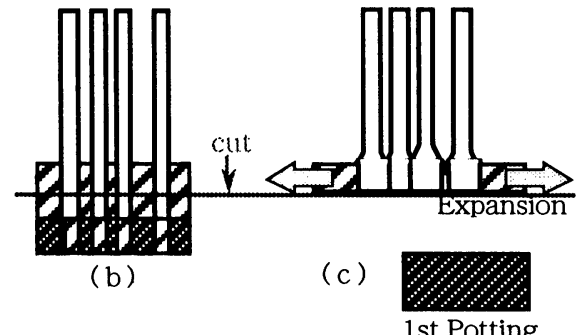

1st Potting
Fig 2 A method for making Intracapillary oxygenator with Expanded inlet
そしてこの試験片を 4 方向に引っ張ることにより, 中空糸 を含むポッティング部分を拡張し, 中空糸流入部の拡大化を 図った.

次にこの拡張した試験片を中空糸断面と平行で互いに直角 な $\mathrm{x}, \mathrm{y}$ 軸方向へ拡張率20〜30\%程度まで拡張した時

(Fig.1) の, 中空糸断面の拡張の様子を実体顕微鏡（ $\mathrm{S} \mathrm{H}$ I MAD ZU : C CD-F1) を用いて観察し，断面径を計 測した. この時, 試験片の厚さに対する, 中空糸断面径の拡 大率を求めた。

\section{2.人工肺の作製}

試験片による拡張により, 圧力損失の低減効果を持った流 入部作製の可能性が示唆されたため, この方法を応用して人 工肺の作製を試みた。

まず，人工肺の設計を行った．膜面積に関しては，円管内 層流熱伝達式および物質移動論の浸透説 ${ }^{10)}$ に基づき, ガス側 （中空系外側）から血液側（中空糸内側）への酸素の物質移 動方程式をたてることにより行った. また, 圧力損失につい ては, 中空糸内流路における摩摖損失を低減すべく, 最終的 に中空糸本数 $25000 \sim 30000$ 本と従来の内部灌流型人工肺の 5000本に対して5６倍に增すこととした. また, 中空系有 効長さを $4 \sim 5 \mathrm{~cm}$ 短く設計することにより，圧力損失の一 層の低減化を図ることとした．これにより通常の中空糸膜型 人工肺に対して太くて短い円柱形状の人工肺を作製すること とした.

最終仕様の人工肺作製に先立ち，約 $1 / 5$ の大きさの人工肺 の試作を行った. 前述した試験片の拡張による中空糸断面の 拡大化が可能であったため, その中空糸形状を維持したまま 第2段階のポッティングを行い, 試験片と同様のシリコーン 中空糸膜を収束し, 流入部の拡張を行った人工肺の試作を試 みた. 人工肺の作製方法をFig.2に示す.

まず，中空糸内側への接着剤流入を防ぐため，中空糸束の 1 端を 1 段目のポッティングにより閉塞した（Fig.2（a）). そして 2 段目のポッティングを行い，その後ポッティング部 分を厚さ3〜 4mmにカットした (Fig.2（b)）．次にその 部分に対し拡張率 (= (拡張後の 1 本の中空糸断面の直径 拡張前の 1 本の中空糸断面の直径）/払張前の 1 本の中空系 断面の直径）6および10\%の桩張を行った（Fig.2（c））. この拡張状態のまま治具により固定し，ハウジング内に中空 糸束を充填し， 3 段目のポッティングを行い，中空系束をハ ウジングに固着させた（Fig.2（d））．最後に 2 段目のポ ッティング部分（拡張部分）をカットし（Fig.2（e））, 断面が拡大したラッパ状の流入部を得た.

試作 $1 / 5$ 人工肺をFig. 3 に示す.この人工肺は中空糸本数 5000 本, ポッティング部分も含めた中空糸長さ $7 \mathrm{~cm}$, 有効 膜面積 $0.6 \mathrm{~m}^{2}$ であった, 流入部拡張実験の結果に基づき, $\mathrm{S} 0$ : 非拡張，S6:6\%拡張，S10：10\%拡張の3種類製作した.

次に, 最終仕様に基づき設計を行い作製した内部灌流型人 工肺をFig.4に示す. 外観は, 直径 $\phi 14 \mathrm{~cm}$, 長さ $12 \mathrm{c}$ 


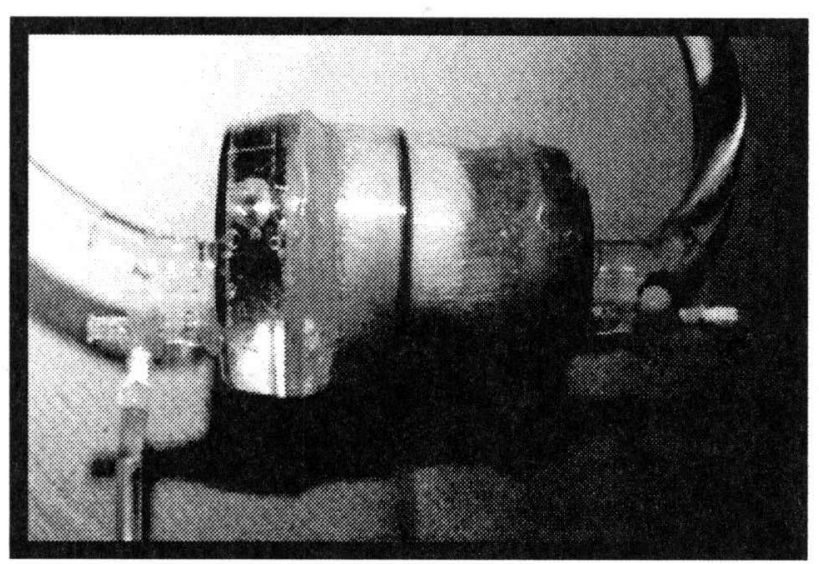

Fig.3 A picture of the Intracapillary oxygenator ( S 0, S 6, S 10$)$

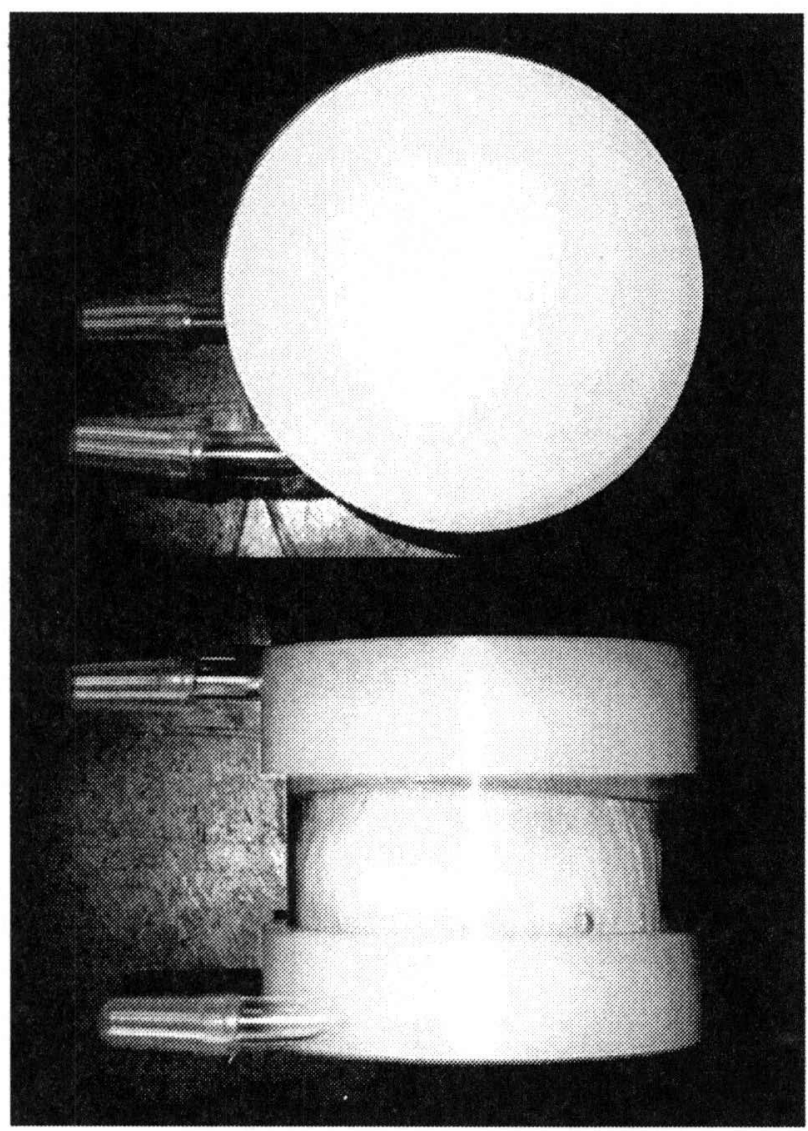

Fig.4 A picture of the made intracapillary oxygenator

$\mathrm{m}$ の円筒形状であり, 従来の中空糸膜型人工肺に比較して太 くて短い形状となっている. 作製方法は, 中空系束を円筒状 に集束し，前述した試作 $1 / 5$ 人工肺と同様の方法にて流入部 および流出部のポッティングを行い, ポリプロピレン製のキ ヤップを被せて作製した.この人工肺は中空系本数 25000 本, 中空糸長さ $8 \mathrm{~cm}$, 有効膜面積約 $3 \mathrm{~m}^{2}$ であった.

\section{3. 人工肺流入部の評価}

試作 $1 / 5$ 人工肺 $\mathrm{S} 0, \mathrm{~S} 6, \mathrm{~S} 10$ により，40\%グリセリン水溶 液を用いて圧力損失の計測を行った.

流量は約 $200,400,600,800 \mathrm{~mL} / \mathrm{min}$, 設計による中 空糸25000 30000本の人工肺の使用流量に換算して, 約 1 , 2，3，4L/minの範囲で灌流した. 中空糸内流路の管レイノ ルズ数は $\mathrm{R} \mathrm{e}=0.8 \sim 3.3$ であった.この時の試作内部灌流型 人工肺の流量に対する圧力損失の計測を行った.

\section{4.人工肺の評価}

最終仕様の内部灌流型人工肺のガス交換能の評価および圧 力損失の計測を行った.

ガス交換能の評価は, A C D 加新鮮牛血を用い標準静脈血

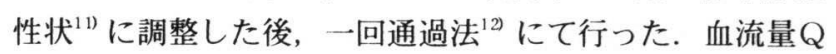
とガス流量 $\mathrm{V}$ の比は $\mathrm{V} / \mathrm{Q}=1,2,3$ とした. 人工肺の血液 入口および血液出口より採血を行った血液は, 血液ガス分析 装置（コーニング248）にてpH, PO2, PCO2, 酸素飽和度 等の血液性状を求めた後, 計算 ${ }^{11}$ により酸素移動量, 炭酸 ガス移動量を求めた.

圧力損失の計測は, 最終仕様の試作 $1 / 5$ 人工肺と同様にし て行った. 血流量は $0.5,1 \mathrm{~L} / \mathrm{min} の$ 範囲にて行った.

\section{3.結果}

\section{1.拡張部の観察結果}

Fig.5に試験片の厚さに対する, 中空糸断面径の拡大率を 示した. Fig.6に実体顕微鏡での拡大画像を示した. 試験片 厚さがそれぞれ $2,3,5 \mathrm{~mm}$ で $\mathrm{x}, \mathrm{y}$ 軸方向の拡張率が最大 值20\%の時, 中空糸断面径の $\mathrm{x}, \mathrm{y}$ 軸方向の実際の拡張率は

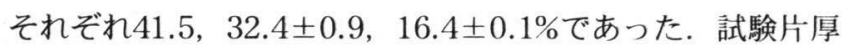
さそれぞれの最大拡張率を越える拡張に於いては, 変形能を 超え破断した. またFig.6より, 中空糸断面の形状は, 試験 片の拡張が $\mathrm{x}, \mathrm{y}$ 軸の 2 万向であったにも関わらずほぼ円形 を維持したまま直径が拡大されていた.

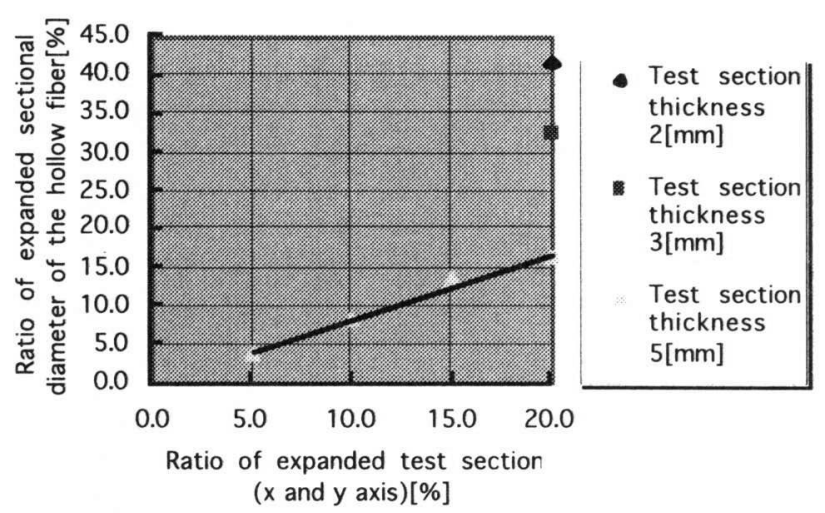

Fig.5 A ratio of expanded sectional diameter of the hollow fiber to expanded test section 


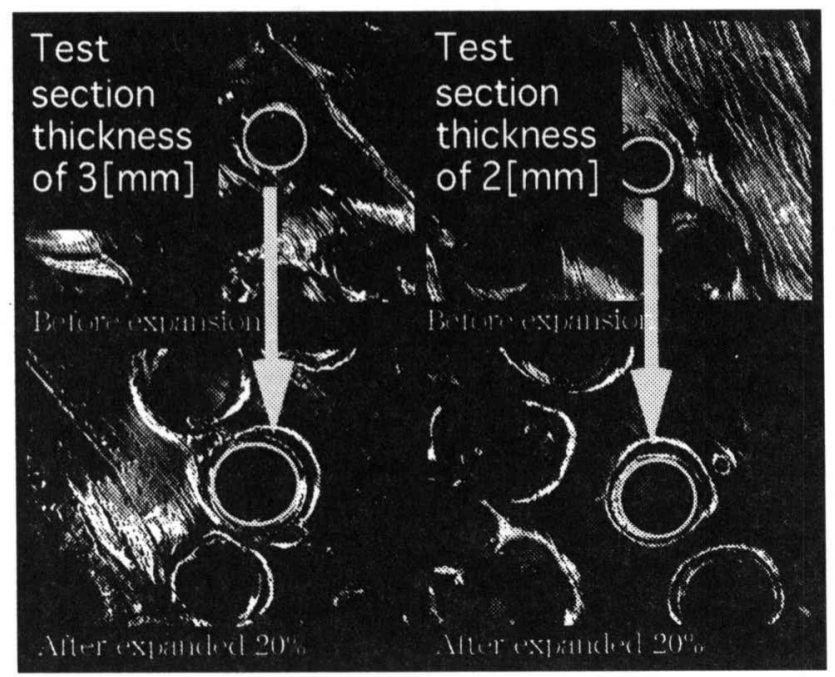

Fig.6 A picture by CCD camera(175 magnifications)

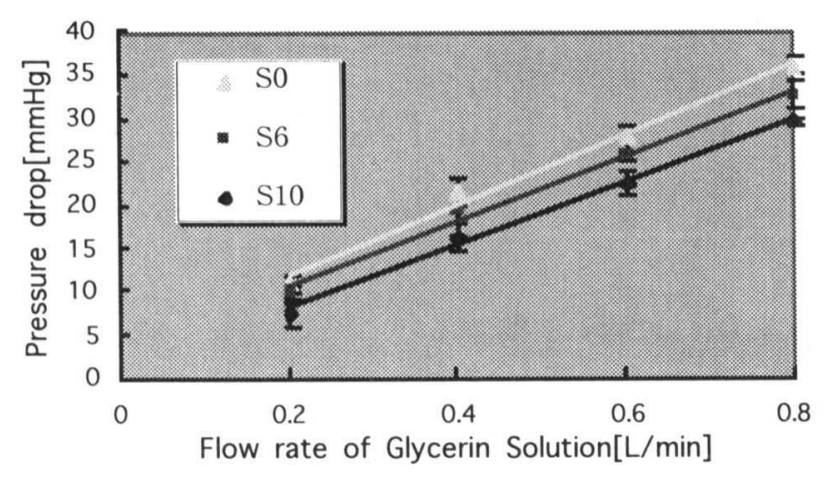

Fig.7 A pressure drop to flow rate of Glycerin Solution

\section{2.圧力損失の評価結果}

Fig.7にグリセリン水溶液流量に対する最終仕様の $1 / 5$ の 大きさを持つ人工肺 $\mathrm{S} 0, \mathrm{~S} 06, \mathrm{~S} 10$ の中空糸内側流路の圧力 損失を比較して示した. 圧力損失はS $0, \mathrm{~S} 6, \mathrm{~S} 10$ の順に従 ってより低值を示した．S0に対するS6，S10の圧力損失は 最大で流量 $0.8 \mathrm{~L} / \mathrm{m} \mathrm{i} \mathrm{n}$ (中空糸本数 25000 の人工肺に換算 して $4 \mathrm{~L} / \mathrm{m}$ i n ) のとき，それぞれ $9.3 \% ， 17.6 \%$ 低減され ていた。 また, 圧力損失の差も流量の増加に伴い増大寸る傾 向が見られた.

\section{3.試作内部灌流型人工肺の評価結果}

Fig.8およびFig.9に血流量に対する最終仕様の内部灌流 型人工肺の酸素移動量および炭酸ガス移動量を示した。

Fig.8より, 酸素移動量は血流量 $0.5,1 \mathrm{~L} / \mathrm{min}$ において, 最 大 $32,52 \mathrm{~mL} / \mathrm{min}$ であった。 またFig.9より, 炭酸ガス移動

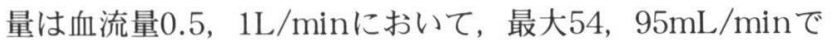
あった。

Fig.10に最終仕様の内部灌流型人工肺の圧力損失を示し た. 血流量 $0.5,1 \mathrm{~L} / \mathrm{min} に お い て ，$ 圧力損失は 13 , 30mmHgであった.

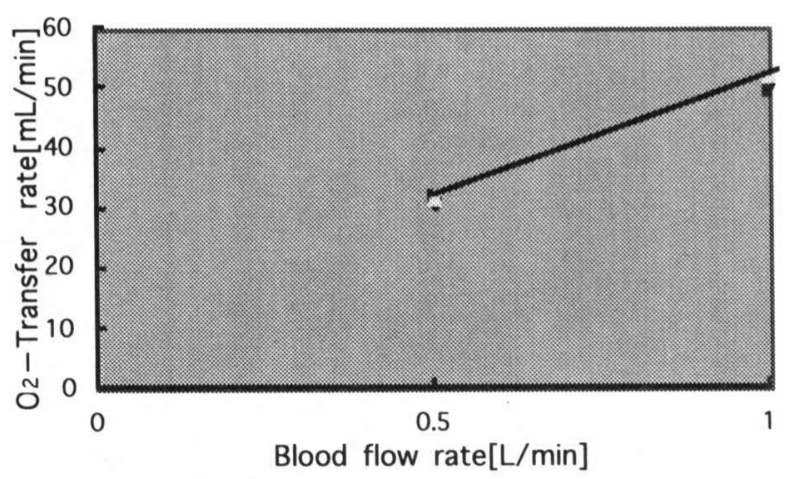

Fig.8 O2-Transfer rate to Blood flow rate

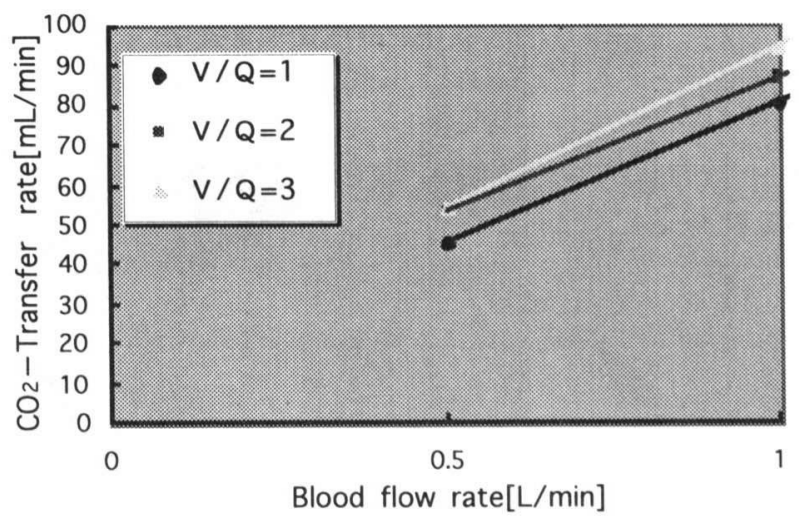

Fig.9 $\mathrm{CO} 2-$ Transfer rate to Blood flow rate

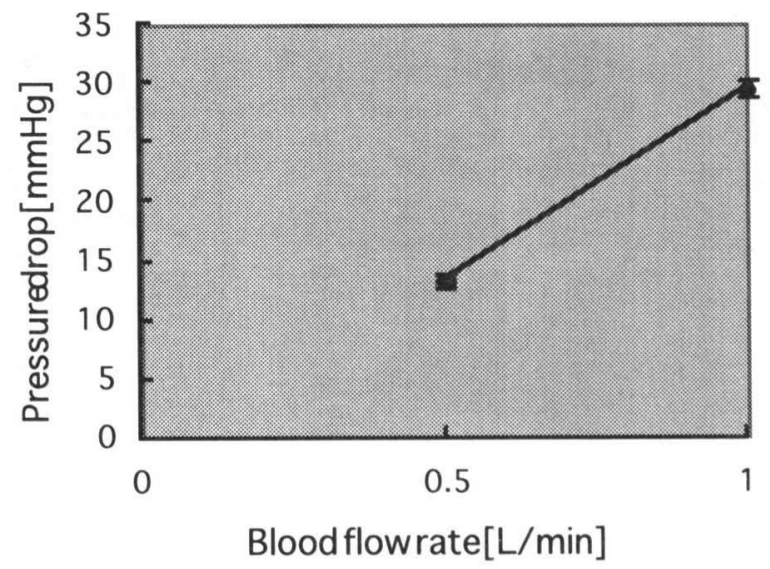

Fig.10 A pressure drop to Blood flow rate

\section{4.考察}

(1) 試験片の拡張

まず，シリコーンゴムの材質は3次元的な分子構造を持ち， かつ柔軟である。このため, 薄い平板状のシリコーンゴム試 験片の端部を把持して4方向に拡張した場合, 試験片の中心 付近ではシリコーンゴムの変形により，あらゆる方向に張力 が分散されたと考えられた. そして，この中心部分に試験片 と同様に柔軟で非常に小口径なシリコーン中空系膜をポッテ 


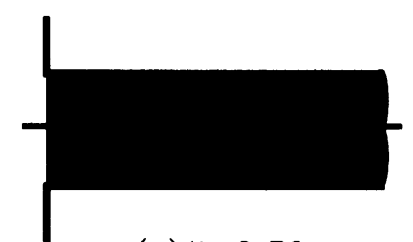

(a) $\zeta=0.50$

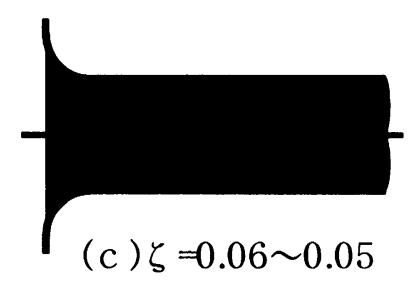

Fig.11 Inlet pressure drop coefficient on the Form of tube inlet $\left(\mathrm{R} \mathrm{e}=2 \times 10^{3}\right)^{13}$

イングし試験片を作成したため，中空糸膜自体はあらゆる方 向から引張力を受け, かつ中空であるために, 実験結果の様 にほぼ真円に近く拡張することができたと考えられた。 また 試験片を薄く製作することで, 試験片拡張率よりも高い中空 糸断面径の桩大率が得られることが判った.

そして, ポッティングによる試験片部分とポッティングさ れていない部分との間の中空糸断面径が中空糸軸方向に進む につれ変化し, 流入部が丸みもしくはテーパのついたラッパ 形状になっていることが示唆された.

また，試験片を薄く製作することで，より高い中空糸膜の 流入部が得られたこと，および拡張部分の破断を招く可能性 から, 拡張を行うポッティング部分は 3 ～4mmの厚さに製作 することが望ましいと考えられた.

\section{（2）人工肺内の圧力損失}

まず, 最終仕様の $1 / 5$ の大きさを持つ人工肺にて圧力損失 の計測実験を行った結果より，中空糸 25000 本の人工肺に換 算して流量 $1 \sim 4 \mathrm{~L} / \mathrm{min}$ の範囲において, 圧力損失が流入部 拡張を行った人工肺 $10 \%$ 拡張時に約 $8 \sim 30 \mathrm{mmHg}, 6 \%$ 拡張 時に約10〜33mmHg, 非拡張の人工肺でも11 $36 \mathrm{mmHg}$ と低い圧力損失を示すことがわかった．これは，流入部拡張 による圧力損失の低減効果に加え, 中空糸長さを短くし, 円 管流路の摩擦損失も低減させた設計を採用したことによるも のと考えられた：そして流入部の拡張を行った人工肺におけ る圧力損失は，搪張を行わなかった中空糸に比較して低值を 示した.これより流入部拡張の効果によって, 流入部におい て圧力損失の低隇が実現されたことが判った.

このことから, シリコーン中空糸膜が柔軟な性質であるた めに, ポッティング部の拡張に伴い中空糸断面が拡大され, 中空糸流路が参考までに示したFig.11の（a）の形状から

（b）や（c）に示した, より流入部損失係数 $ら$ の低い形状 (ただしらの值は乱流域において得られたものである) ${ }^{133} に$ 成っていると考えられた.

また, この結果より, 流入部における損失係数を求めた. Fig.12に人工肺S0, S06, S10より求められたレイノルズ数

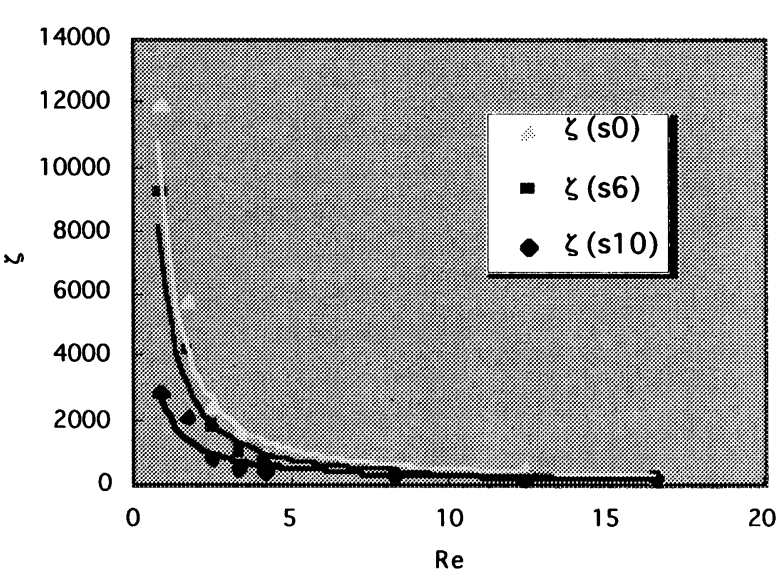

Fig.12 Inlet pressure drop coefficient to Reynolds number

（Re）に対する流入部損失係数らを示す．Fig.12より，一 般に言われるように低レイノルズ数になるほど損失係数が高 くなるという傾向が見られ，また流入部の抎張率の增加に対 し, 損失係数の減少が確認された. そして, 試作 $1 / 5$ 人工肺 の使用領域である, 低レイノルズ数領域で, 流入部拡張を行 わない場合, 流入部損失俰数が非常に高值を示していること が判った.

（3）試作内部灌流型人工肺の評価

酸素移動量については, 全領域にて良好なガス交換能を示 した.これは, 外部灌流型人工肺のような血液の摚汼効果は 持たないが，試作内部灌流型人工肺の膜面積が $3.0 \mathrm{~m}^{2}$ と多い 為, そして高ガス交換能が得られる新規な小口径シリコーン 中空糸膜を用いた為であると考えられた．また炭酸ガス移動 量についても, 全流量において良好なガス交換能を示した. これは, 酸素移動量と同様の条件によると考えられるが, そ れ以外に酸素に比較して血液側とガス側の分圧が低いと考え られる炭酸ガスの移動量が高かったのは, 内部灌流方式によ り血液側に比較的高い剪断力が働いた為, 赤血球の酸素の吸 収が促進され ${ }^{14}$ ，それに伴い炭酸ガスの放出が促進されたた めであると考えられた.

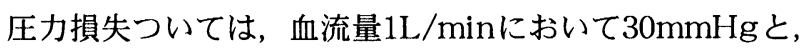
試作 $1 / 5$ 人工肺の非拡張のタイプにおける $11 \mathrm{mmHg}$ よりも 高值を示していた.この原因は, 試作内部灌流型人工肺内の 中空糸本数が多いために一部で充分に流れていない可能性や， ポッティングミスによる中空糸の閉塞などが考えられた.し かし, この試作内部灌流型人工肺の圧力損失は, 膜面積が異 なるため同レベルでの比較はできないが, 現在市販されてい る内部灌流型人工肺における值（数百 $\mathrm{mmHg}$ ）に比較して 低い值を示していた。

これらより，シリコーン中空糸膜を用いた低圧力損失な内 部灌流型人工肺の可能性が示され, 今後は $\mathrm{E} C \mathrm{MO}$ 等の長期 呼吸補助用の人工肺としての応用も十分に可能であると考え られた. 


\section{5.結言}

1.柔軟なシリコーン中空糸膜により, 中空糸流入部での圧力 損失の低減効果が得られた。

2.シリコーン中空系膜を用いて, 流入部拡張ポッティングに よる，内部灌流型人工肺を試作した。

3.内部灌流型人工肺に新規なシリコーン中空糸膜を用い，か つ圧力損失が低減されたことで, 長期呼吸補助用人工肺と しての有用性が示唆された.

今後は, 中空糸膜で構成されるガス交換部の微小な流路だ けではなく, キャップなど人工肺全体の流路のデザインも改 善し, 高ガス交換能でより血栓の少ない人工肺の開発を目指 し，長期にわたる評価を行っていく必要があると思われた.

\section{参考文献}

1）横山秀雄, 井上紀雄, 佐々木昭彦, 前川功二, 道井洋吏, 小松作蔵 : 外部灌流方式hollow fiber膜型肺M A X I M AおよびWilliam Harvey HF4000の臨床的比較検討, 人工臓器 $16: 687$ (1987)

2 ）末田泰二郎，福永信太郎，村上康宣，浜中喜晴，石原 浩, 松浦雄一郎： HFPPVによる積層型膜型肺の酸素 加の試み, 人工臓器 19：589（1990)

3 ）村本智則, 建部 建, 野川淳彦, 萩原和彦, 清田由紀夫, 深沢弘道, 佐渡峯生, 稲葉 章, 高橋 晃: 新規な人工 肺用多孔質中空糸の開発，人工臟器 $19: 472$

(1) 1990 )

4) 舟久保昭夫, 福井康裕, 佐藤耕司郎：小口径シリコーン 中空糸膜を用いた外部灌流型人工肺の開発，人工臓器 25 (1): :68-70 (1996)

$5)$ Akio Funakubo, Tetsuya Higami, Ichiro Sakuma, Yasuhiro Fukui,Tsuyoshi Kawamura, Koshiro Sato, Akinori Sueoka and Yukihito Nose: Development of a Membrane Oxygenator for ECMO Using a Novel Fine Sillicone Hollow Fiber, A S I O JOURNAL 42(5) : M837-M840(1996)

6) 樫村隆司, 千葉 浩, 竹澤真吾, 酒井清孝, 中西 光, 井上政昭 : 外部灌流膜型人工肺のガス交換能の評価, 人 工臟器 16 （3）：670-673（1987）

7 ) 加茂 純, 浜田栄一, 山藤家嗣, 中島 敦, 鎌田健資, 吉原敏雄, 福井康裕, 河村剛史 : 微多孔質中空糸膜を使 用した新規な人工肺の試作と実験的検討, 人工臟器 14 (3) : 1637-1640（1985)

8 ）大村朋幸, 永瀬道臣, 桑名克之, 中西 光, 井上政昭, 酒井清孝: 外部および内部灌流膜型人工肺におけるガス 交換能, 人工臓器 17 （3）：1446-1449 (1) 998 8

9）舟久保昭夫, 福井康裕, 佐久間一郎, 嗵上哲哉, 河村剛 史 : 膜型人工肺内の血液の流れの 3 次元計測・表示法の 㭘討：人工臟器掲載予定（1997)
10 ）水科篤郎，萩野文丸：輸送現象（第 4 刷）：241 -242（1998）産業図書株式会社

11 ) Association for the Advancement of Medical Instrumentation .Standard for blood/gas exchange device (Oxygenator) draft,1982

12 ）野村 望, 川嶋康生, 藤田 毅, 岡本重一, 橋本総一, 曲直部寿夫 : 人工肺ガス交換能の指標に関する研究, 日本胸部外科学会誌 $23: 1402$ (1975)

13 ）日本機械学会編，機械工学便覧（新版第5刷），A 5 - 77 (1 977 ) :Weisbach,J.:Ingenieur- und Maschienen-Mechanik, I : 1003 (1896)

14 ）沖野 遥, 菅原基晃, 松尾祐英 : 心葴血管系の力学と 基礎計測（第2刷）：44（1982） 